2017 Vol 1. No II

\title{
ZAKAT LEMBAGA DALAM PERSPEKTIF EKONOMI ISLAM
}

\section{Hermansyah}

\begin{abstract}
The formality of zakat leaves problems in determining who is subject to zakat. If we refer to the rules of classical fiqh, then the only assets that must be zoned for use are precious metals (gold and silver), livestock (camels, cows and goats), agriculture, commerce, mining and found goods. In fact, at present there are many large sources of income outside this sector. The world of industry, entertainment and other service businesses is a field of income that is far greater than that of farmers.
\end{abstract}

Keywords: Zakat, tax, institutions, islamic economic 


\section{Vol 1. No II}

\section{Pendahuluan}

Rendahnya motivasi menunaikan zakat selama ini tidak lepas dari wawasan kitab-kitab fiqh zakat yang hanya membahas persoalan zakat dari segi subtansi hukumnya tanpa mengemukakan secara jelas urgensi dan tujuannya terutama konsep keadilan secara utuh sebagai suatu yang mengandung berbagai nilai.

Formalitas zakat menyisakan persoalan dalam hal penentuan kena zakat. Jika kita mengacu pada aturan fiqh klasik, maka harta yang wajib dizakati hanya logam mulia (emas dan perak), ternak (onta, sapi dan kambing), pertanian, perniagaan, barang tambang dan barang temuan. Padahal, di masa kini banyak sumber-sumber penghasilan besar terdapat diluar sektor tersebut. Dunia industri, entertainment dan bisnis-bisnis jasa lainnya merupakan ladang penghasilan yang jauh lebih besar tingkat pendapatannya daripada pendapatan petani. Sebagai contoh sebuahperusahaan yang pada hakikatnya mewakili pemilik modal atau saham yang menghasilkan keuntungan yang berlipat ternyata belum banyak disentuh dalam fiqh klasik, lalu bagaimana syariah melihat fenomena tersebut? Tulisan ini akan mencoba mengalborasi lebih jauh.

\section{Zakat dalam Perspektif Fiqh dan jenis serta Syarat Harta yang dizakatkan}

Zakat menurut bahasa bermakna berkembang, bertambah dan berkah. Menurut istilah fiqh berarti sejumlah harta yang diwajibkan Allah SWT untuk diserahkan kepada orang-orang yang berhak. Diantara landasan kewajiban zakat berpijak pada dalil yang bersifat umum, seperti termakstub dalam Q.S Al Baqarah ayat 267 yang artinya "Wahai orang-orang yang beriman, nafkahkanlah (dijalan Allah) sebagian dari hasil usahamu yang baik-baik...” juga firman Allah SWT dalam Q.S. At Taubah ayat 103 yang artinya "Ambilah zakat dari sebagian harta mereka dengan zakat itu kamu membersihkan dan mensucikan mereka.

Disamping itu juga didukung oleh hadis riwayat Imam Bukhari dari Anas bin Malik yang menyatakan "Janganlah digabungkan sesuatu yang terpisah dan jangan pula dipisahkan sesuatu yang tergabung (berserikat) karena takut mengeluarkan zakat. Dan apa-apa yang telah digabungkan dari dua orang yang telah berserikat (berkongsi) maka keduanya harus dikembalikan (diperlakukan) secara sama”. 


\section{Vol 1. No II}

Terdapat beberapa jenis harta yang dizakatkan yakni: emas dan perak, tanaman dan buahbuahan, hasil usaha dan hasil perut bumi termasuk binatang ternak. Adapun syarat-syarat harta kekayaan yang dikenai zakat adalah: hak milik sempurna, produktif dan berkembang yakni kekayaan itu dapat atau berpotensi mendatangkan hasil, keuntungan atau pendapatan kepada pemiliknya, mencapainisab yakni batas minimal kekayaan untuk dikenai zakat, kelebihan dari kebutuhan pokok dan sudah mencapai haul yakni sudah berlalu satu tahun. Ketentuan ini berlaku pada zakat emas dan perak, binatang ternak dan barang dagangan. Sedangkan pada hasil pertanian, harta karun, barang tambang tidak dikenai haul.

Dari uraian diatas maka dalam pembahasan selanjutnya mengenai zakat lembaga sangat terkait dengan jenis harta yang dizakatkan menyangkut hasil usaha dan syarat harta yang dikenai zakat menyangkut harta produktif dan berkembang.

\section{Zakat Lembaga dalam Ekonomi Islam}

Lembaga merupakan suatu badan hukum yang kedudukannya diakui seperti perseorangan dalam hukum yang memiliki hak serata kewajiban. Lembaga dapat dibedakan menjadi dua yakni: lembaga produktif yakni lembaga yang menghasilkan keuntungan (misal perusahaan) dan lembaga yang tidak menghasilkan keuntungan (misal lembaga pemerintahan). Karenanya dari klarifikasi tersebut jika dikaitkan dengan jenis dan syarat harta yang wajib dizakatkan, maka hanya lembaga yang menghasilkan keuntungan yang dikenai zakat.

Ulama kontemporer sepakat wajib mengeluarkan zakat dari tempat yang menghasilkan uang seperti toko, bangunan, perusahaan dan lain-lain. Alasannya bahwa tempat tersebut dianggap produktif dan menghasilkan keuntungan atau kekayaan yang melimpah selama harta itu bisa berkembang. Pada masa lalu zakat jenis ini tidak dikenal karena standar waktu itu adalah barang yang tidak produktif dan tidak diketahui bentuk mana yang merupakan penghasilan.

Berdasarkan hal ini, keberadaan lembaga sebagai wadah usaha kemudian menjadi badan hukum atau syakhsiyyah i'tibariyyah. Sebab diantara individu itu kemudian timbul transaksi, meminjam, menjual, berhubungan dengan pihak luar, dan menjalin kerja sama. Segala kewajiban dan hasil akhirpun dinikmati bersama, termasuk didalamnya kewajiban kepada Allah SWT dalam bentuk zakat. Namun diluar zakat lembaga, tiap individu juga wajib mengeluarkan zakat 


\section{Vol 1. No II}

sesuai dengan penghasilan dan nisabnya. Para ulama kontemporer menganalogikan zakat lembaga ini dengan zakat perdagangan, karena dipandang dari aspek legal dan ekonomi kegiatan sebuah lembaga yang intinya berpijak pada kegiatan perdagangan (trading).

Secara umum berbagai bentuk dalam pola pembayaran dan perhitungan zakat mengacu pada pola pembayaran dan perhitungan zakat mengacu pada pola pembayaran dan perhitungan zakat perdagangan sebagaimana pendapat kebanyakan ulama adalah senilai nisab emas dan perak yakni 85 gram emas (pendapat paling mu'tabar) sedangkan tarifnya adalah 2,5\% dari asset, bukan dari keuntungan. Landasan perhitungannya adalah sebagaimana yang diriwayatkan oleh Abu Ubaid dalam kitab Al-Amwal "Apabila telah sampai batas waktu membayar zakat, perhatikanlah apa yang engkau miliki baik uang (kas) ataupun barang yang siap diperdagangkan (persediaan), kemudian nilailah dengan nilai uang lalu hitunglah hutang-hutangmu dan kurangkanlah atas apa yang engkau miliki."

Perhitungan zakat lembaga tersebut dinilai dari seluruh penghasilan yang diperoleh selama satu tahun dikurangi semua jenis pembiayaan yang dilakukan. Misalnya biaya pemeliharaan, biaya penyusutan, dana pembelian peralatan, biaya promosi, gaji pegawai dan sebagainya. Jika perusahaan masih memiliki tanggungan utang pada pihak lain, maka cicilan pembayaran utang dimasukkan kedalam faktor pengurang penghasilan.

Adakalanya sebuah perusahaan memiliki sejumlah utang yang harus dibayar dalam jangka waktu tertentu dan berkewajiban mengembalikannya secara tunai atau berkala. Cicilan yang harus dibayar setiap tahun itulah yang menjadi faktor pengurang. Piutang tidak termasuk perhitungan zakat karena pada hakikatnya kekayaan yang dipiutangkan (dipinjamkan) pada pihak lain tidak memenuhi syarat sebagai harta yang wajib dibayar zakatnya. Piutang merupakan harta yang bukan sepenuhnya milik perusahaan karena berada ditangan orang lain sehingga perusahaan tidak bisa menguasai sepenuhnya serta tidak bisa menggunakan harta tersebut. Ketika piutang telah dibayar, barulah kewajiban zakat dikenakan. Apabila sisa penghasilan dikurangi semua biaya selama satu tahun memenuhi satu nishab, perusahaan mengeluarkan zakat sebesar $2,5 \%$.

Dari penjelasan dia atas, maka pola perhitungan zakat perusahaan didasarkan pada laporan keuangan (Neraca) dengan mengurangkan kewajiban lancar atas aktiva lancar. Metode 


\section{Vol 1. No II}

perhitungan ini biasa disebut dengan metodesya'iyyah. Yang perlu diperhatikan dalam perhitungan zakat perusahaan adalah pentingnya melakukan berbagai koreksi atas nilai aktiva lancar dan kewajiban jangka pendek yang kemudian disesuaikan dengan ketentuan syariah. Seperti koreksi atas pendapatan bunga, dan pendapatan tidak halal (haram) serta pendapatan subhat lainnya. Sedangkan asset tetap tidak termasuk yang diperhitungkan ke dalam harta yang dikenakan zakat, karena asset tersebut tidak untuk diperjualbelikan. Zakatnya adalah selisih kali $2,5 \%$.

\section{Perhitungan Zakat Lembaga atau Perusahaan}

Zakat perusahaan atau lembaga hampir sama dengan zakat perdagangan. Bedanya dalam zakat perusahaan bersifat kolektif. Dengan kriteria sebagai berikut: (1) jika perusahaan bergerak dalam bidang usaha perdagangan maka perusahaan tersebut mengeluarkan harta sesuai dengan aturan zakat perdagangan. Kadar zakat yang dikeluarkan sebesar 2,5\%; (2) jika perusahaan tersebut bergerak dalam bidang produksi maka zakat yang dikeluarkan sesuai dengan aturan zakat investasi atau pertanian. Dengan demikian zakat perusahaan dikeluarkan pada saat menghasilkan sebesar 5\% atau 10\%. 5\% untuk penghasilan kotor dan 10\% untuk penghasilan bersih. Jika dalam perusahaan tersebut ada penyertaan modal dari pegawai non muslim maka perhitungan zakat setelah dikurangi kepemilikan modal atau keuntungan dari pegawai non muslim.

Pola perhitungan zakat perusahaan, didasarkan pada laporan keuangan (Neraca) dengan dikurangi kewajiban atas aktiva lancar. Atau, seluruh harta (diluar aktiva tetap) ditambah keuntungan, dikurangi kewajiban lainnya, sisanya jika mencapai nishab maka wajib dikeluarkan zakatnya sebesar saham wajib mengeluarkan 2,5\%. Pendapat tersebut sebagaimana disampaikan Abu Ubaid dalam kitab Al-Amwaal (ada yang berpendapat zakat yang wajib dikeluarkan hanya dari keuntungan saja). 
2017 Vol 1. No II

Sebagai contoh. PT XY adalah sebuah perusahaan yang bergerak dibidang konveksi. Pada akhir tahun 2014 memiliki Neraca sebagai berikut:

\section{Aktiva Lancar:}

Kas

Rp. 2.000.000,-

Bank

Rp. 3.000.000,-

Piutang Dagang

Rp. 5.000.000,-

Persediaan Bahan Baku

Rp. 3.000.000,-

Persediaan Bahan Jadi

Rp. 2.000.000,-

Total Aktiva Lancar

Rp. 15.000.000,-

Total Aktiva Tetap

Rp. 43.000.000,-

Total Aktiva

Rp. 58.000.000,-

Berdasarkan data diatas, maka perhitungan zakatnya sebagai berikut: Aktiva Lancar Utang Lancar = Rp. 15.000.000,- - misal Rp. 5.500.000,- = Rp. 9.500.000,- Jadi besarnya zakat yang dikeluarkan adalah 2,5\% X Rp. 9.500.000,- = Rp. 237.500,--

\section{Zakat dan Pajak}

Banyak orang berusaha menyamakan antara zakat dan pajak, sehingga konsekuensinya ketika seseorang sudah membayar pajak maka gugurlah pembayaran zakatnya. Sementara sebaian lain menolak bahwa zakat sama dengan pajak atau sebgai alternatif dari kewajiban zakat. Zakat dan pajak adalah dua pungutan wajib yang memiliki karakteristik berbeda. Jika dilihat secara cermat memang ada persamaan antara zakat dan pajak, namun disisi lain banyak juga perbedaannya.

Berikut ini akan diuraikan tentang persamaan antara zakat dan pajak yakni: (1) bersifat wajib dan mengikat atas harta penduduk suatu negeri, apabila melalaikannya terkena sanksi; (2) zakat dan pajak harus disetorkan pada lembaga resmi agar tercapai efisiensi penarikan keduanya dan alokasi penyalurannya. Dalam pemerintahan Islam, zakat dan pajak dikelola oleh negara; (3) 


\section{Journal Competency of Business}

2017 Vol 1. No II

tidak ada ketentuan memperoleh imbalan materi tertentu di dunia; (4) dari sisi tujuan ada kesamaan antara keduanya yakni untuk menyelesaikan problem ekonomi dan mengentaskan kemiskinan yang terdapat di masyarakat.

Tabel 1. Perbedaan antara zakat dan Pajak

\begin{tabular}{|c|c|c|}
\hline Perbedaan & Zakat & Pajak \\
\hline Nama Berarti & $\begin{array}{l}\text { Bersih, bertambah dan } \\
\text { berkembang }\end{array}$ & Utang, pajak, upeti \\
\hline Dasar Hukum & Al Qur'an dan As Sunnah & UU suatu negara \\
\hline Nishab Dan Tarif & $\begin{array}{l}\text { Ditentukan Allah SWT dan } \\
\text { bersifat mutlak }\end{array}$ & $\begin{array}{l}\text { Ditentukan oleh Negara dan } \\
\text { bersifat relatif nishab zakat } \\
\text { memiliki ukuran tetap } \\
\text { sedangkan pajak berubah- } \\
\text { ubah sesuai dengan neraca } \\
\text { anggaran Negara }\end{array}$ \\
\hline Sifat & $\begin{array}{l}\text { Kewajiban bersifat terus } \\
\text { menerus }\end{array}$ & $\begin{array}{l}\text { Kewajiban } \\
\text { dengankebutuhan dan dapat } \\
\text { dihapuskan }\end{array}$ \\
\hline Subyek & Muslim & Semua Warga Negara \\
\hline Obyek Alokasi Penerima & Tetap 8 golongan (ashnaf) & $\begin{array}{l}\text { Untuk dana pembangunan } \\
\text { dan anggaran rutin }\end{array}$ \\
\hline Harta Yang Dikenakan & Harta produktif & Semua harta \\
\hline Motivasi Pembayaran & $\begin{array}{l}\text { Keimanan dan ketaqwaan } \\
\text { kepada Allah SWT dan } \\
\text { ketakutan pada Negara dan } \\
\text { saksinya }\end{array}$ & $\begin{array}{l}\text { Ada pembayaran pajak } \\
\text { dimungkinkan adanya } \\
\text { manipulasi besarnya jumlah } \\
\text { harta wajib pajak dan hal ini } \\
\text { tidak terjadi pada zakat. }\end{array}$ \\
\hline
\end{tabular}




\section{Journal Competency of Business}

\section{Vol 1. No II}

Kaitannya dengan pembayaran pajak dan zakat sekaligus yang notabene keduanya merupakan kewajiban maka UU Pajak No.17 Tahun 2000, pasal 9 huruf g dinyatakan bahwa zakat yang dibayarkan pada BAZ atau LAZ yang sah (yang terdaftar di dinas terkait) dapat menjadi pengurang penghasilan kena pajak. Zakat yang dibayarkan dihitung sesuai dengan ketentuan syariah di atas yang selanjutnya dikurangkan atas penghasilan kena pajak. Misalnya nilai harta perusahaan yang kena zakat adalah Rp. 100 juta, maka zakatnya adalah Rp. 2,5 juta, kemudian nilai tersebut dikurangi atas penghasilan kena pajak.

Ketentuan dalam pasal ini sesuai dengan pasal 14 ayat 3 UU Pengelolaan zakat. Pembayaran zakat yang lebih sedikit seperti di atas merupakan akibat tidak langsung dari pengurangan oleh pembayaran zakat. Maksudnya, setelah dikurangi zakat, jumlah penghasilan yang akan dikenakan pajak akan berkurang sehingga dengan prosentase yang tetap, nilai pajaknya pun akan semakin kecil. Dengan adany UU pajak No. 17 Tahun 2000 tersebut, maka biaya yang dikeluarkan untuk zakat menjadi faktor pengurang bagi pembayaran pajak, sehingga biaya yang dikeluarkan wajib pajak untuk membayar pajak pun lebih sedikit dari semestinya. 


\section{Journal Competency of Business}

\section{Vol 1. No II}

\section{Penutup}

Dari uraian di atas dapat disimpulkan: (1) harta yang berpotensi mendatangkan hasil, keuntungan atau pendapatan kepada pemiliknya dapat dikenai zakat seperti halnya lembaga yang produktif; (2) zakat lembaga dianalogikan dengan zakat perdagangan jika bergerak dibidang perdagangan, dengan zakat pertanian jika dibidang produksi dan diasumsikan sama dengan zakat profesi jika berbentuk jasa; (3) zakat tidak sama dengan pajak. Keduanya merupakan kewajiban yang sama-sama dijalankan akan tetapi zakat dapat dikurangkan dari pajak sesuai dengan UU Pajak No. 17 Tahun 2000, pasal 9 huruf g. 


\section{Journal Competency of Business}

\section{Vol 1. No II}

\section{Daftar pustaka}

Anwar Syamsul, Studi Hukum Islam Kontemporer. Jakarta: RM Books 2007.

Ahmad Wahyu Herdianto. "Peran Negara dalam Mengoptimalkan Zakat di Indonesia." Jurnal Jurisdictie. Jurnal Hukum dan Syariah IAIN Raden Fatah Palembang. Volume 1 Nomor 2 Desember 2010.

Dierktorat Pengembangan Zakat dan Wakaf Dirjen Bimas Islam dan Penyelenggaraan Haji. Manajemen Pengelolaan Zakat. Jakarta Kemenag RI, 2005.

Gazi Inayah, Teori Komprehensip tentang Zakat dan Pajak. Terj. Zainudin Adnan \& Nailul Falah. Yogyakarta: Tiara Wacana. 2003.

http://ekonomisyariah.org/does/detail_cara.php?idkatagori=7

http://www.republika.co.id/ramadan/detail.asp?id=265740\&kat_id=164\&kat_id1=265

Johan Wahyu Wicaksono. "Zakat Sebagai Salah Satu Instrumen Kebijakan Fiskal Dan Implikasinya Terhadap Pemerataan.” Jurnal ekosiana. Juranl Ekonomi Syariah STAI An Najah Surabaya. Volume 1 Nomor 1 Maret 2014.

Masdar F Mas’udi. Agama Keadilan: Risalah Zakat (Pajak) dalam Islam (Jakarta: Pustaka Firdaus, 1991)

M. Amin Rais, Tauhid Sosial, Formula Menggempur Kesenjangan, Cet III. Bandung: Mizan, 1998.

Nuruddin Mhd Ali. Zakat Sebagai Instrumen Dalam Kebijakan Fiskal Ed.I. Jakarta: PT. Raja Grafindo, 2006.

Qadir, Abdurrahman, Zakat: Dalam Dimensi Mahdhah dan Sosial, Jakarta: Grafindo Persada. 1998.

Saifuddin. “Optimalisasi Distribusi Dana Zakat: Upaya Distribusi Kekayaan (Studi Terhadap UU No. 23 Tahun 2011 tentang Pengelolaan Zakat).” Jurnal Az Zarqa’. Jurusan Muamalat Fakultas Syariah Dan Hukum IAIN Sunan Kalijaga Yogyakarta. Volume 5 Nomor 2 Desember 2013.

Ugi suharto. Keuangan Publik Islam: Reintepretasi Zakat Dan Pajak. Yogyakarta: Pusat Studi Zakat STIS Yogyakarta, 2004.

Yusuf Al Qardawi, Hukum Zakat. Jakarta: Pustaka Litera Antarnusa. 1998

Yusuf Qardhawi, Fatwa-fatwa Kontemporer, Jakarta: Gema Insani Press, 1995. 